\title{
CADASTRAL DATA AS A BASIS FOR RATIONAL USE AND PROTECTION OF LAND
}

\author{
Tykhenko Olha, Bavrovska Nataliia \\ National University of Life and Environmental Sciences of Ukraine
}

\begin{abstract}
Without cadastral information, it is difficult to make any decisions about land. But in order for the system of state land cadastre to work effectively, it is necessary that the information in it is up-to-date, complete and reliable. The article analyzes in detail the existing legislative and regulatory acts and draws conclusions from the methodological principles of keeping the state land cadastre in the part concerning the consideration of factors of influence on the quality of land accounting. The status of agricultural land use was monitored and land conservation measures recommended. The authors have analyzed in detail the public information on the soil cover of Ukraine, which is displayed on the Public Cadastral Map of Ukraine. The necessity of enrichment of the cadastre with new information and indicators is investigated, which allows to solve a wider range of problems regarding the use of land as a spatial basis and the purpose of development of the multifunctional cadastre.
\end{abstract}

Keywords: the state land cadastre, rational use, land plot.

\section{Introduction}

Cadastral data should be the basis for rational land use and protection, which implies the creation of a favorable ecological environment and the improvement of natural landscapes. In the crisis situation of the livestock industry in Ukraine, when the livestock population has fallen sharply and the production and application of manure has fallen significantly, there is a need to find ways of replenishing the organic part of the soil through the use of alternative organic fertilizers. Reliable information on the quality of the land as a whole and in particular the soil cover should be reflected in the national cadastre system (Tykhenko, 2016; Bavrovska, 2016). Land use in Ukraine should be considered in the context of multipurpose use, which is defined by the legal norms of land use.

Many countries also consider it desirable to develop plans for improving agriculture and developing the rural economy. Mapping data on land use provides the necessary basis for the accumulation and classification of knowledge about available resources (FAO, 2003).

The basis of rational use and protection of land should be reliable information of the state land cadastre on soil cover. Unfortunately, in Ukraine, this information is mostly outdated, and the soil layer is informative in relation to the soil cover of Ukraine. At the same time, the following layers were created in 2019-2020 to plan measures for rational land use and land use control: "Classification of crops 2019 (Yarov)," Classification of crops 2019 (Winter) "," Crops on unregistered lands in $2019 »$ That are informative in nature and allow you to track the current state of crops.

Nevertheless, the debate about the nature and contents of the inventory of land as a mean of obtaining, updating and correcting information on the status of land ownership and land use, which entered into the State Land Cadastre of Ukraine are continuing nowadays.

The purpose of the article is to analyze the data of the state land cadastre of Ukraine on the information needed for rational land use and to identify the shortcomings that have emerged. In order to achieve this goal, the following tasks have been solved: The state land cadastre has been filled with data on agricultural land; the reliability of information on the soil cover of Ukraine as a basis for rational land use is investigated.

\section{Methodology of research and materials}

The object of the research - the cadastral information system of Ukraine (Public cadastral map of Ukraine). The article discusses the publicly data that is present on the Public Cadastral Map. The following methods were used for the research: monograph (in elaboration of scientific works on problems of rational land use); abstract-logical (when substantiating the theoretical basis of cadastral data as a basis for rational use and protection of land); analysis and synthesis (for a comprehensive assessment and justification of the current state of filling the cadastral system, analysis of foreign cadastral systems); systematic, statistical 


\section{Results and discussion}

It should be noted that it is very important that land use is possible only on the basis of complete cadastral data (András Osskó, Jan K., B. Sonnenberg, 2002; D. Platonova, A. Jankava, 2012; Irene Suárez Fernández, 2008). Land consolidation can be an effective tool for rural development through better management of natural resources, rationalization of land ownership structure, and prevention of potential conflicts arising from land restructuring for other uses (Platonova, \& Jankava, 2012). Land consolidation must address the problems of land fragmentation and be ensured by a permanent institutionalized body. The cadastre and registration system is an important source of information on the mapping of individual parcels and real estate objects using cadastral maps in land consolidation (Irene Suárez, 2008).

The cadastral system is the main source of accurate information about land plots and their attributes. Land information systems have a number of advantages, given both the definition of rights and registration of existing land rights, value and use, and changes that affect human-land relations according to the changing nature of land rights, land value; and land use in general (Abdeslam Moulay Adad, 2019).

Both in Ukraine and in the world, there is a clear trend towards the development of a multifunctional cadastre based on various information on land resources. This creates new opportunities for enhancing the rights of landowners and land users, enriching the cadastre with new data and metrics, enabling a wider range of land use and spatial use (Kovalyshyn, \& Kryshenyk, 2018; Tykhenko, 2018). The formation of the modern land cadastre system was influenced by the social and economic transformations that took place in society: the land cadastre has evolved from a accounting system to a modern information system, the data of which should be the basis for efficient, environmentally sound land use.

The state land cadastre is maintained for the purpose of providing information to state authorities and local self-government bodies, individuals and legal entities in the organization of rational use and protection of land (Law Ukrainy, 2011). According to Article 33 of the Law of Ukraine "On the State Land Cadastre", the quality of land records reflects the data characterizing the lands by natural and acquired properties, affecting their productivity and economic value, as well as by the degree of manmade pollution of soils. In accordance with the Law of Ukraine "On Land Protection", the following standards are set in the field of land protection and soil fertility reproduction: maximum permissible soil contamination; the quality of the soil; optimal ratio of land; indicators of land and soil degradation. The maximum permissible soil contamination standards are determined in order to establish criteria for the suitability of land for their intended use.

The rational use of the land depends directly on its purpose, because only by operating a clearly defined purpose of land exploitation can develop a list of specific methods of its use, determine the peculiarities of the allocation of productive forces within the land, establish the composition of land, and control the rational land use. The current level of fertility of agricultural land is catastrophically low.

The regulatory purpose of the cadastre for agricultural land is based on the effective use of land resources to provide the population of the country with food and agricultural raw materials - industry, as well as the introduction of a system of measures for the protection of land resources, including the preservation and reproduction of soil fertility. Therefore, the primary task of landowners and land users is to constantly restore the fertility of the land, and this can be achieved through its rational use.

One of the main tasks of the cadastre of Ukraine is to fill in $100 \%$ of the State Land Cadastre with reliable and complete information about land plots, boundaries of administrative-territorial units, regulatory monetary valuation and data on indicators of land quantity and quality accounting. Thus, the State Land Cadastre of Ukraine has entered information about $73 \%$ of land plots, of which 13.9 million agricultural land plots with a total area of 30.4 million hectares (Figure 1, Table 1).

As a moratorium on the sale of agricultural land was introduced in Ukraine, it had a significant impact on the types of transactions for agricultural land. Yes, the lease is $76.1 \%$, the inheritance is $18.33 \%$, and the mine-donation transactions are only $1.6 \%$ (Figure 2 ).

The territory of Ukraine is 60.357 million hectares, of which 42.724 million hectares (or $70.8 \%$ ) are agricultural land. Of these, $98.6 \%$ are rural and only $1.4 \%$ are urban. In rural areas, the share of agricultural land is the largest among other purpose land (71.9\%), followed by forests and arable land (17.5\%). In cities, the largest share is built-up land (housing, industrial land, etc.) - $35.3 \%$, and agricultural $-31.1 \%$. The characteristics of the purpose of land and the distribution of forms of ownership differ significantly between administrative and territorial units. 


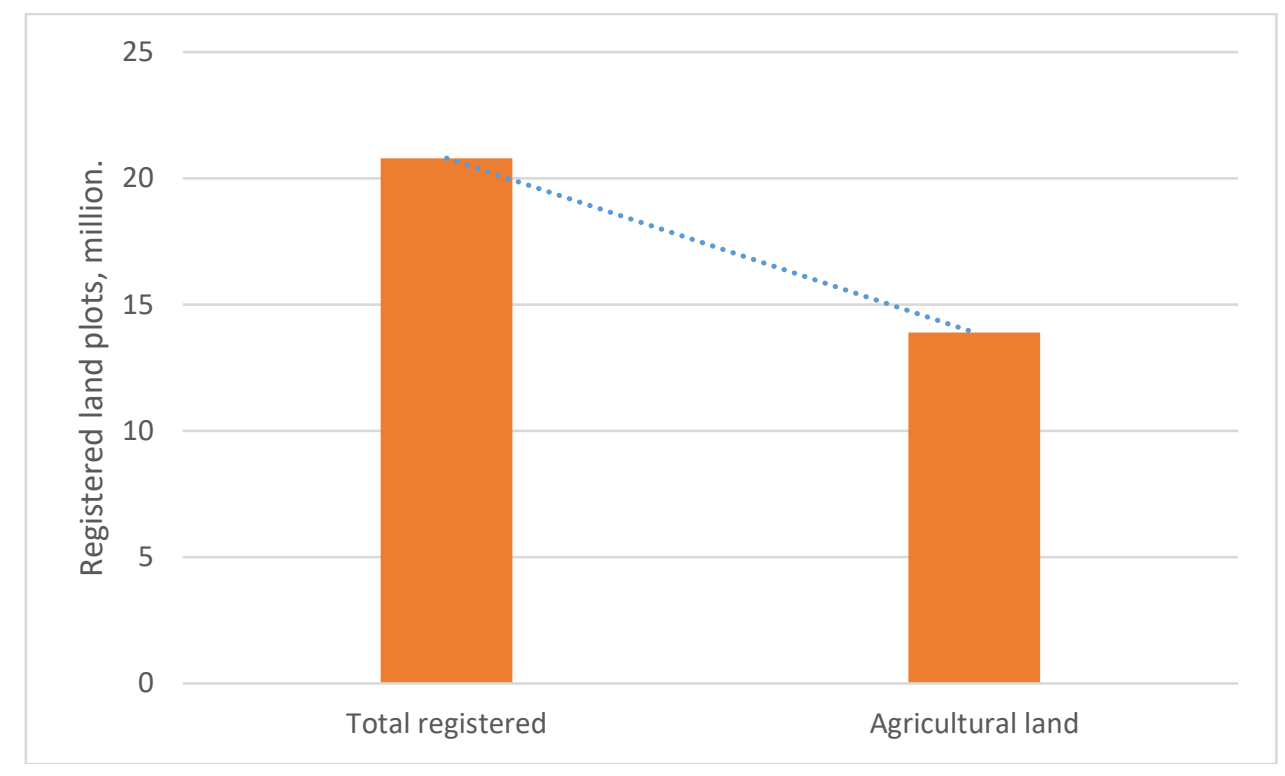

Figure 1. Information about the agricultural land plots entered in the state land cadastre, 2019 (Compiled according to the State Geocadastre of Ukraine).

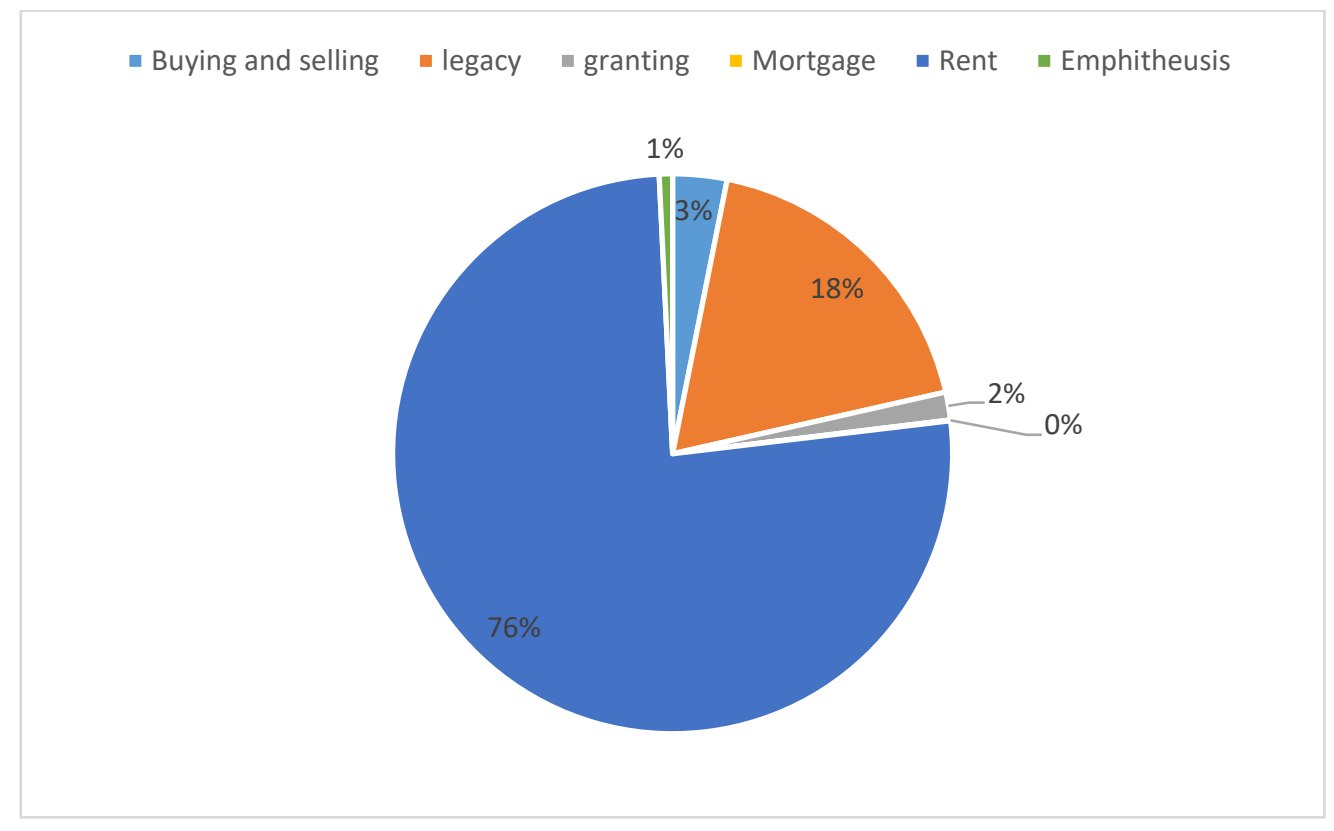

Figure 2. The share of types of transactions among agricultural land

Analyzing the data in Table 1, we can see that in Ukraine the largest percentage of unregistered land in the state land cadastre is in the Zakarpatska and Ivano-Frankivsk regions and the Autonomna Republica Krym (more than 50\%). Only Vinnytsia, Dnipropetrovsk, Zaporizhia, Khmelnytskyi Cherkassy regions the state land cadastre contains the most information about land plots. 
Table 1

Information on land outside the settlements, which are not included in the automated system of the State Land Cadastre (on 01.10.2019)

\begin{tabular}{|c|l|c|c|c|}
\hline No & $\begin{array}{c}\text { Name of administrative } \\
\text { territorial unit }\end{array}$ & $\begin{array}{c}\text { Total area region, } \\
\text { thous. hectares }\end{array}$ & $\begin{array}{c}\text { Area of } \\
\text { unregistered land, } \\
\text { thous.hectares }\end{array}$ & $\begin{array}{c}\text { The } \\
\text { percentage of } \\
\text { unregistered } \\
\text { land (\%) }\end{array}$ \\
\hline 1 & Vinnytsia region & 2646.4 & 428.8 & 16.2 \\
\hline 2 & Volyn region & 2013.2 & 816.6 & 40.6 \\
\hline 3 & Dnipropetrovsk region & 3192.1 & 433.5 & 13.6 \\
\hline 4 & Donetsk region & 2636.7 & 774.9 & 29.4 \\
\hline 5 & Zhytomyr region & 2983.1 & 969.7 & 32.5 \\
\hline 6 & Zakarpatska region & 1275.9 & 790.4 & 61.9 \\
\hline 7 & Zaporizhia region & 2723.1 & 507.1 & 18.6 \\
\hline 8 & Ivano-Frankivsk region & 1385.1 & 717.3 & 51.8 \\
\hline 9 & Kyiv region & 2815.6 & 904.7 & 32.1 \\
\hline 10 & Kirovohrad region & 2456.7 & 537.2 & 21.9 \\
\hline 11 & Lugansk region & 2667.5 & 1105.1 & 41.4 \\
\hline 12 & Lviv region & 2153.3 & 1006.2 & 46.7 \\
\hline 13 & Mykolayiv region & 2462.4 & 550.3 & 22.3 \\
\hline 14 & Odesa region & 3327.4 & 970.0 & 29.1 \\
\hline 15 & Poltava region & 2868.0 & 595.1 & 20.7 \\
\hline 16 & Rivne region & 2005.3 & 479.3 & 23.9 \\
\hline 17 & Sum region & 2369.3 & 605.8 & 25.6 \\
\hline 18 & Ternopil region & 1382.0 & 286.1 & 20.7 \\
\hline 19 & Kharkiv region & 3140.0 & 997.5 & 31.8 \\
\hline 20 & Kherson region & 2946.7 & 796.2 & 27.0 \\
\hline 21 & Khmelnytskyi region & 2047.9 & 361.0 & 17.6 \\
\hline 22 & Cherkassy region & 2083.0 & 297.5 & 14.3 \\
\hline 23 & Chernivtsi region & 808.6 & 303.1 & 37.5 \\
\hline 24 & Chernigiv region & 2609.5 & 1463.8 & 56.1 \\
\hline 25 & Autonomous Republic of Crimea & & & \\
\hline & & & 935.6 & \\
\hline
\end{tabular}

Therefore, land reform and restrictions on the land market must take into account local characteristics. The poor state of land resources in terms of their environmental and economic performance indicates the need to optimize land use. No effective mechanisms for protection of especially valuable lands have been created so far.

One of the systematic manifestations of the cadastre is the Public Cadastral Map, as a way to simpler and more convenient relations with citizens and with the state apparatus. In each country there is a national system of cadastral structuring, which takes into account the specific features of the economy and geographical location of the country, its traditions, the mentality of the nation, etc. and, most importantly, performs its functions. Since 2013, orthophoto plans have become the cartographic basis for Ukraine's public cadastral map. New layers have been created when developing a single integrated inventory system that will contain information about the country's natural resources. They can serve as a powerful tool for displaying land use and further a basis for developing a set of land use and conservation measures. Yes, the soil layer, which was created by vectorization of the soil map of Ukraine M 1: 200 000, but it is informative in relation to the soil cover of Ukraine. Although, for the rational use and protection of agricultural land, information on soil cover is paramount and necessary.

As the soil cover of Ukraine is very diverse, there are about 800 soil types, their detailed examination and actual display on the soil map is necessary. Black Earth soils, along with high productive fertility, are susceptible to degradation, which is often due to their irrational use. Humus is the main source of energy for the processes of conversion of mineral compounds into soil and an integral indicator of soil fertility. 
The use of soil solely as a source of profit without concern for its protection, excessive plowing has led to a critical condition of soil in Ukraine. In Ukraine, 57.5\% of agricultural land is undergoing erosion and these processes continue. Saturation of crop rotations with intensive mineral nutrition, significant reduction of fertilizer application, spread of erosion processes have led to a negative balance of humus in many regions of Ukraine. That is why it is necessary, in addition to displaying the soil cover itself in the land cadastre, to map the quality maps of the soil of Ukraine.

\section{Conclusions}

1. Lack of qualitative characteristics of land plots in the cadastral system of Ukraine significantly complicates state control over land use and protection, as there are no grounds for levying fines for reducing soil fertility.

2. Soil quality standards determine the level of contamination, optimal nutrient content, physicochemical properties. These indicators should be the main source of information for the formation of the National Cadastral System database on land quality characteristics and the basis for rational land use and protection.

3. The information of the soil layer on the public cadastral map of Ukraine not only does not correspond to the nomenclature list of agricultural production groups of soils, but is also inaccurate in some places, as it is related to the obsolescence of soil information, which was based on large-scale soil surveys, which are already extensively surveyed. Decades have not been spent.

4. Geospatial data is the basis for developing and monitoring adherence to a country's development strategy, a tool for integrating it into the global information space, and transforming the cadastre into a multi-purpose is a relevant and timely task. The poor state of land resources in terms of their environmental and economic performance indicates the need to optimize land use.

5. To obtain reliable information on the state of agricultural land, a state program of land protection measures is required, with detailed surveys involving landowners and users using leased land.

\section{References}

1. Бавровська Н.М., Боришкевич О.В. (2016) Проблеми використання та охорони сільськогосподарських земель в сучасних умовах (The problems use and protection of agricultural land in modern conditions). Землеустрій, кадастр і моніторинг земель. № 1-2. с. 53-61. (in Ukrainian) DOI: http://dx.doi.org/10.31548/zemleustriy2016.01.053

2. Ковалишин О. Ф., Кришеник Н. I (2018). Удосконалення методичних підходів до формування правових обмежень під час використання земельних ділянок у системі державного земельного кадастру (Improvement of methodic approaches to formation of legal restrictions while using land parcels in the system of the state land cadastre). Науковий вісник НЛТУ України, 28(4), 78-82. (In Ukrainian). https://doi.org/10.15421/40280414

3. Про Державний земельний кадастр (On the State Land Cadastre Law of Ukraine) (2011). Закон України від 07.07.2011 № 3613-VI. (In Ukrainian).

4. Тихенко О.В. (2016) Раціональне використання сільськогосподарських земель: проблеми та перспективи їх вирішення (Rational use farmland: problems and prospects of settlement). Землеустрій, кадастр i моніторинг земель. № 1-2. с. 71-86. (in Ukrainian). http://dx.doi.org/10.31548/zemleustriy2016.01.076

5. Тихенко О.В. (2018) Особливості формування багатоцільового кадастру в Україні (Peculiarities of the formation of a multi-purpose cadastre of Ukraine). ). Землеустрій, кадастр і моніторинг земель. № 2. с. 50-54. (in Ukrainian). http://dx.doi.org/10.31548/zemleustriy2018.02.050

6. Abdeslam Moulay Adad (2019). The Cadastral and Land Information Systems for an Effective Land Governance. Geospatial Technologies for Effective Land Governance Morocco. 2019. 18 P. (ANCFCC, Morocco) DOI: 10.4018/978-1-5225-5939-9.ch013

7. Andras Ossko, Jan K. B. Sonnenberg (2002). The Netherlands. Rural Land Markets in Central and Western Europe. FIG XXII International Congress Washington, D.C. USA, April 19-26.

8. Irene Suarez Fernandez (2008). Land consolidation in Norway. A study of a multifunctional system, Lugo, February. PP 50-63.

9. Platonova D., Jankava A. (2012). Description of Land Fragmentation in Latvia and its Prevention Opportunities. Proc. Latvia University of Agriculture (LLU), 28(323). DOI: 10.2478/v10236-012-0009-y. 
10. The place of cadastral surveys and registration of rights in rural development (1995). Binns, B.O., 1953. Cadastral surveys and records of rights in land. FAO Land Tenure Series 1. Updated by P.F.Dale, 1994. Food and Agricultural Organisation of the United Nations.

\section{Information about authors}

Olha Tykhenko, Ph.D. in Agriculture Sciences, Associate Professor, Department of Land Cadastre, Faculty of Land Management, National University of Life and Environmental Sciences, Ukraine, Kyiv 03040, Vasylkivska str., 17, olgavfrank@ukr.net

Nataliia Bavrovska, Ph.D. in Economics, Associate Professor, Department of Land Cadastre, Faculty of Land Management, National University of Life and Environmental Sciences, Ukraine, Kyiv 03040, Vasylkivska str., 17, natali_bavrovska@ukr.net 